\title{
Mortality trends in Erbil, Iraq, 2007-2011
}

\author{
Aso Zangana, ${ }^{1}$ Haitham Al-Banna ${ }^{2}$ and Tariq Al-Hadithi ${ }^{2}$
}

${ }^{1}$ Directorate of Health of Erbil, Ministry of Health, Erbil, Iraq. ${ }^{2}$ Department of Community Medicine, College of Medicine, Hawler Medical University, Erbil, Iraq. (Correspondence to: Haitham Al-Banna: drhaithambahoo@yahoo.com).

\begin{abstract}
Background: Reliable and valid information on trends of mortality and common causes of death is essential to guide priorities for the allocation of resources within the health sector in order to improve health services for the population, increase longevity and improve quality of life.

Aims: This study aimed to determine crude, gender, age and cause specific death rates and to examine mortality trends in a five-year period between 2007 and 2011 in Erbil City, Iraq.

Methods: This study researched 16780 deaths registered at the statistical unit of the Directorate of Health, Irbil City. Data were reviewed and cleared for the purpose of analysis. Causes of deaths were classified according to body systems.

Results: The average crude death rate was 3.1 per 1000 population with male predominance over females in all the years of study (3.5 and. 2.7, respectively). The age-specific death rates were high in the old and middle age groups in addition to the under 5 years age group. Accidents and circulatory diseases were the leading causes of deaths with rates of 65.2 and 58.3/100 ooo population, respectively.

Conclusions: An accurate identification of cause of death suggests that the only use of the death certificate in Erbil is for the purpose of burial and legal issues, and therefore it is imperative for educational efforts to achieve a complete and comprehensive death registration.

Keywords: Mortality, deaths, death certificate, Erbil, cause of death.

Citation: Zangana A; Al-Banna H; Al-Hadithi T. Mortality trends in Erbil, Iraq, 2007-2011. East Mediterr Health J. 2019;25(5):315-321 https://doi. org/10.26719/emhj.18.042

Received: 10/08/16; accepted: 23/10/17

Copyright ( ) World Health Organization (WHO) 2019. Some rights reserved. This work is available under the CC BY-NC-SA 3.0 IGO license (https:// creativecommons.org/licenses/by-nc-sa/3.o/igo).
\end{abstract}

\section{Introduction}

Recent decades have shown great progress in health and survival rates throughout the world. According to the United Nations' 2010 Revision of World Population Prospects, life expectancy at birth for the world's population as a whole rose from 48 years in 1950-1955 to 68 years in 2005-2010 (1). This progress in health and survival needs supporting policies and programmes for the control of diseases and injuries, which should be based on current and timely information concerning the nature of health problems related to the magnitude and distribution of populations. Undoubtedly the most widely available and commonly used data for these purposes are statistical data on the number of deaths by age, sex and cause (2). Data concerning mortality and life expectancy are both important indicators for population health due to the provision of information on the effects of social and physical environmental factors, behavioural and genetic risk factors, and the level and quality of healthcare provided (3). Information on child and adult mortality rates and causes are clearly important for national and regional health polices, and to monitor the impact of interventions and progress towards targets such as Millennium Development Goals (4).

Vital registration of death is regarded as the 'gold standard' for mortality statistics, since it provides continuous and timely information on the causes of death on an annual basis, although registration of death through census series and surveys of population change can also be applicable (5). It is very important that the leading causes of death should be determined as accurately as possible and also determine the age group at which most deaths occur to provide a community assessment (6). In Erbil, Iraq, the statistical unit of the Directorate of Health (DoH) receives monthly reports on deaths from various health settings in the city, including the main hospitals and the forensic medicine centre, which legally issues death certificates that contain information on age, gender and other sociodemographic variables including information on the person who notified the death.

Information on cause of death and approximate interval between onset of disease and death are adopted from the international form of medical certification of cause of death recommended by WHO (1979) (7). The statistical unit also receives data on deaths occurring outside the health settings from the Office of Births and Deaths. This office issues death certificates for deaths occurring at home and buried without approval of health authorities. Such cases are usually referred from courts; therefore, they lack information on cause of death. This study was carried out to determine the crude death rate, gender, age and cause-specific death rates; and to determine trends of mortality in Erbil between 2007 and 2011. 


\section{Methods}

Erbil is the capital of Kurdistan Region of Iraq; in 2011, its population was 1233240 people (8). Data on deaths were obtained from the statistical unit of the DoH of Erbil in a Microsoft excel sheet. The sheet provides information on sociodemographic characteristics of the deceased in addition to cause of death. However, the cause of death was not properly identified in most deaths, often indicated using non-specific terms. These terms often describe the mechanism of death rather than the actual or direct cause of death. The causes of death were classified and grouped according to the International Classification of Diseases (ICD-9) (9). The causes of death were categorized according to the body system, in addition to another three categories: accidents and injuries, cancers, and congenital anomalies.

The number of deaths registered in the study period 2007-2011 was 16780 deaths. This included 12111 deaths reported from the health settings and the forensic medicine centre, and 4669 deaths from the Office of Births and Deaths, thereby constituting $27.8 \%$ of all deaths registered in Erbil during the study period. Both data sets were used to calculate crude death rates and gender specific death rates. The WHO Standard Population was used for the purpose of standardization and calculation of age standardized death rates (10).

The protocol of the study was approved by the research ethics committee of the College of Medicine, Hawler Medical University. Official permission was obtained from the DoH of Erbil and Kurdistan Regional Statistical Office (KRSO) of the Ministry of Planning (MoP) for data collection.

Statistical analysis was done using SPSS-Version 19. Chi-Square test was used for testing association between variables. $P<0.05$ was considered statistically significant.

\section{Results}

In all years of study, male deaths were higher than female deaths, with males' death rate at 3.5/1000 while that of females was $2.7 / 1000$ population. The average crude death was 3.1/1000 population. There was a steady decline in the death rate from 3.6/1000 population in 2007 to $2.5 / 1000$ in 2009 , followed by an increase reaching

Figure 1. Crude death rates in Erbil City from 2007-2011 (per 1000 population)

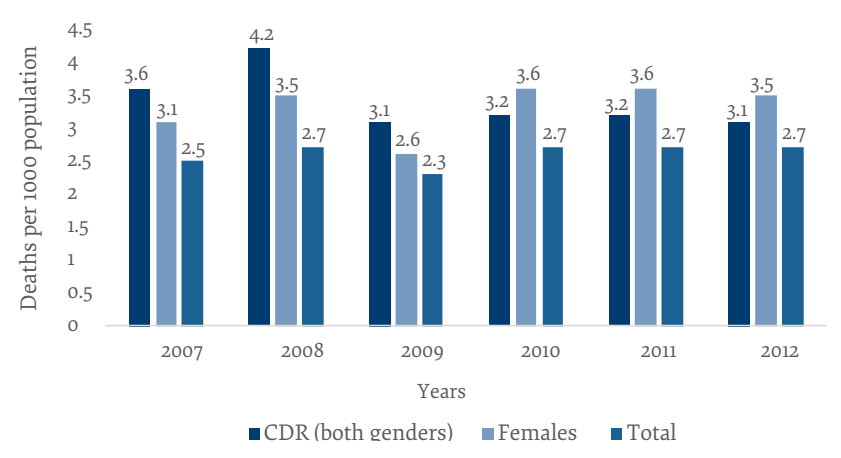

Figure 2 Age standardized death rates per 1000 population for the years 2009, 2010 and 2011 population)

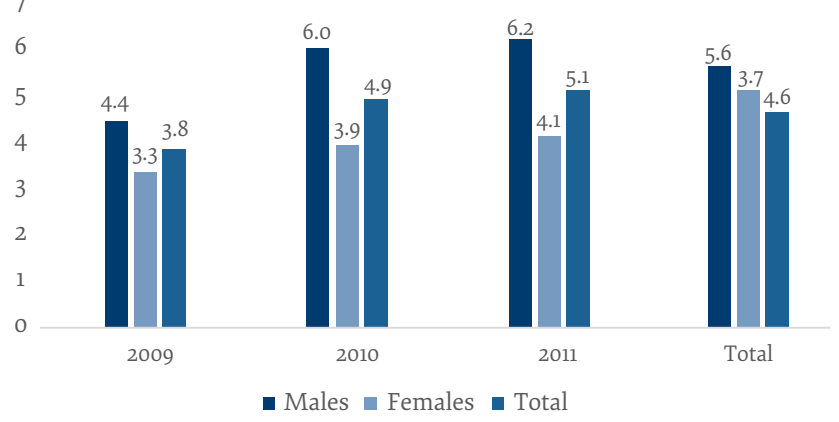

3.2/1000 population in 2010 and 2011 (Figure 1). Calculation of age standardized death rate (ASDR) for the years 2009, 2010 and 2011 revealed an average ASDR of 4.6/1000 population with a gradual increase from 3.8/1000 in 2009 to $5 \cdot 1 / 1000$ population in 2011 (Figure 2). The highest death rate was found in those 75 years of age and more, followed by the age groups 65-74, 55-64 and those less than 5 years of age. In general, there is steady increase in death rates with increasing age after the first 5 years of life, which demonstrated a relatively high death rate (Figure 3).

The average under 5 mortality rate (U5MR) was 23.5/1000 live births, while the average infant mortality rate (IMR) was 20.1/1000 live births for the 5-year period of the study. It is clear that infant mortality constituted the majority of deaths. Infant mortality rate was lowest in 2010 with IMR of 18.1/1000 live births and highest in 2007 with IMR of $25.8 / 1000$ live births, while the U5MR was lowest in 2009 with a rate of 21.0/1000 live births and highest in 2007 with a rate of 29.1/1000 live births (Table 1). The most common cause of death in the study period was accident and injury, constituting $29.1 \%$ of total deaths at 65.24/100 000 population, followed by diseases of the circulatory system constituting $25.5 \%$ at $57.27 / 100000$ population, disorders of the respiratory system constituting $18.9 \%$ at $42.43 / 100$ ooo population, and cancer constituting $7.9 \%$ at $15.60 / 100000$ population. All cause-specific deaths rates were higher in males than females with the exception of death rates for endocrine and metabolic diseases and for other non-specified

Figure 3 Age standardized death rates per 100,000 of population in Erbil city between 2009 and 2011

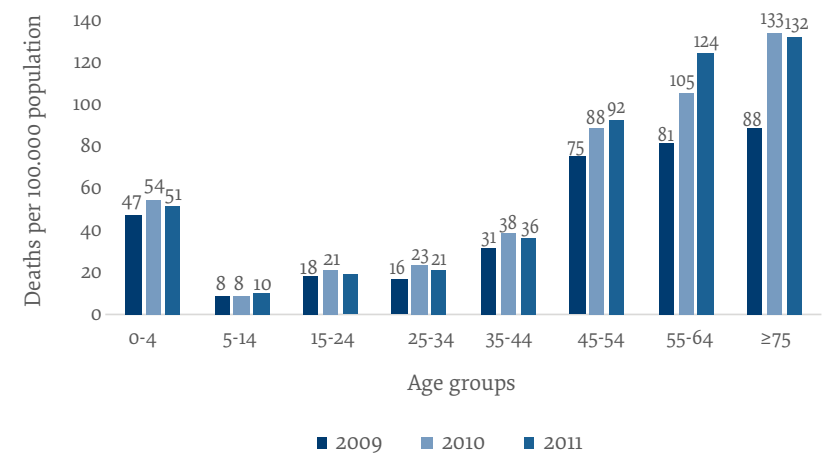


causes (Table 2). Burns, road traffic accidents and bullet injuries constituted $83.7 \%$ of accidents and injuries. Other causes included explosions, electric shock, drowning, stab wounds and strangulation.

Trends of cause-specific death rates indicated that accidents and injuries, diseases of the circulatory system and disorders of the respiratory system (in that order) were the major three causes of death between 2007 and
2009. After 2009, deaths due to diseases of the circulatory system increased sharply and occupied first position in 2010 and 2011, while accidents and injuries moved from first to second position until 2011. Disorders of the respiratory system were in third position in all years of the study. Diseases of blood and blood forming organs and cancers occupied fourth and fifth positions in 2007 and 2008, while between 2009 and 2011 cancers occupied fourth position (Figure 4).

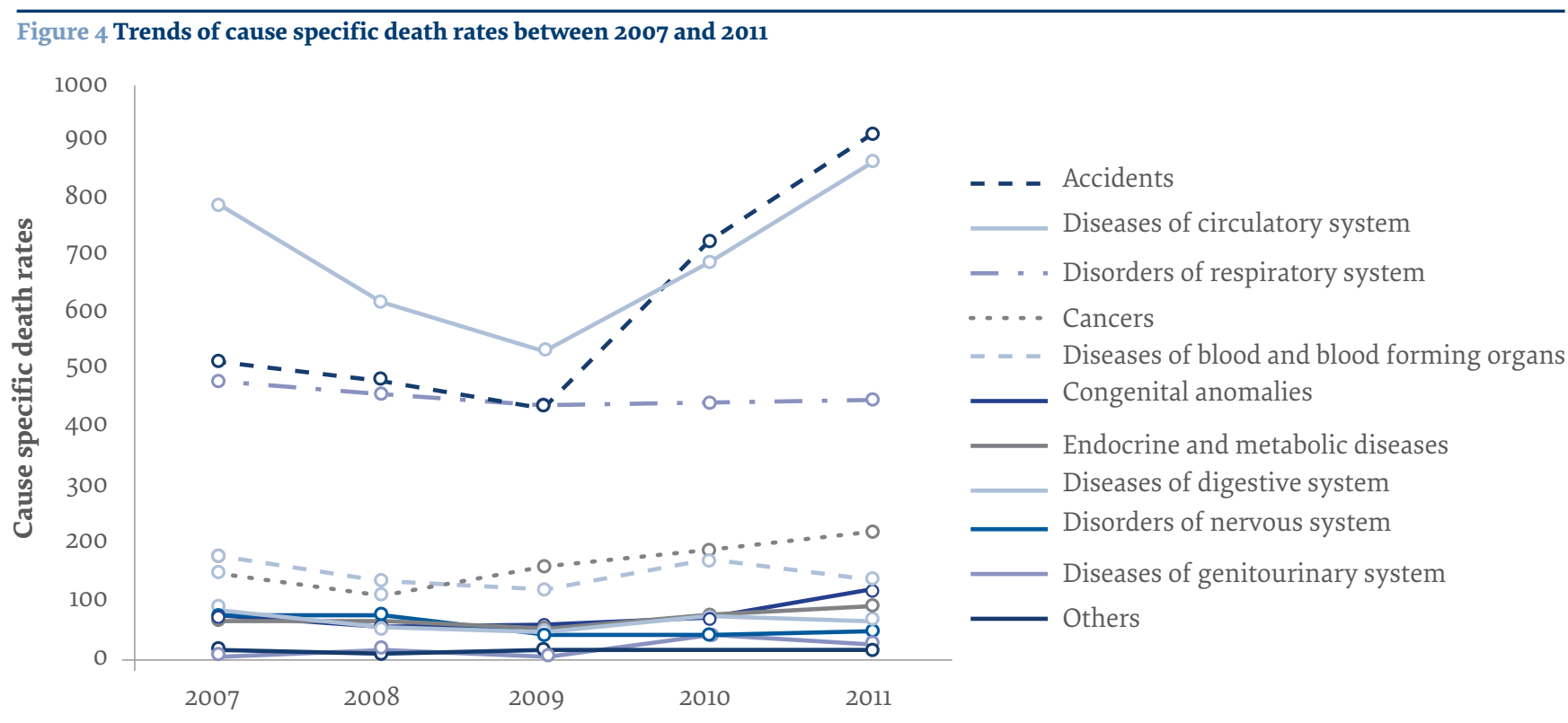

\begin{tabular}{cccccc}
\hline \multicolumn{2}{c}{$\begin{array}{c}\text { Table 1. Trends of infant and under } \mathbf{5} \text { mortality rate per } \mathbf{1 0 0 0} \text { live births in the study period } \\
\text { Year }\end{array}$} & $\begin{array}{c}\text { No. of live } \\
\text { births }\end{array}$ & Infant mortality rate & \multicolumn{2}{c}{ Under $\mathbf{5}$ mortality rate } \\
\cline { 3 - 6 } & & No. of deaths & $\begin{array}{c}\text { Rate/1000 live } \\
\text { births }\end{array}$ & $\begin{array}{c}\text { No. of deaths } \\
\text { Rate/1000 live } \\
\text { births }\end{array}$ \\
\hline 2007 & 28897 & 746 & 25.8 & 842 & 29.1 \\
2008 & 31262 & 652 & 20.9 & 766 & 24.5 \\
2009 & 33198 & 608 & 18.3 & 696 & 21.0 \\
2010 & 38662 & 698 & 18.1 & 841 & 21.8 \\
2011 & 38363 & 720 & 18.8 & 862 & 22.5 \\
\hline
\end{tabular}

Table 2. Cause specific death rates for both genders

\begin{tabular}{|c|c|c|c|c|c|c|c|}
\hline \multirow[t]{2}{*}{ Causes of deaths } & \multicolumn{2}{|c|}{ Males } & \multicolumn{2}{|c|}{ Females } & \multicolumn{2}{|c|}{ Total } & \multirow[t]{2}{*}{$P$ value } \\
\hline & No. of deaths & $\begin{array}{c}\text { Rate per } \\
100000 \\
\text { population }\end{array}$ & No. of deaths & $\begin{array}{c}\text { Rate per } \\
100000 \\
\text { population }\end{array}$ & No. of deaths & $\begin{array}{c}\text { Rate per } \\
100000 \\
\text { population }\end{array}$ & \\
\hline Accidents & 2030 & 74.5 & 1491 & 55.8 & 3521 & 65.24 & $<0.001$ \\
\hline $\begin{array}{l}\text { Diseases of } \\
\text { circulatory system }\end{array}$ & 1704 & 62.6 & 1387 & 51.9 & 3091 & 57.27 & $<0.001$ \\
\hline $\begin{array}{l}\text { Disorders of } \\
\text { respiratory system }\end{array}$ & 1323 & 48.6 & 967 & 36.2 & 2290 & 42.43 & 0.421 \\
\hline Cancers & 499 & 18.3 & 343 & 12.8 & 842 & 15.60 & $<0.001$ \\
\hline
\end{tabular}


Table 2. Cause specific death rates for both genders (concluded)

\begin{tabular}{|c|c|c|c|c|c|c|c|}
\hline \multirow[t]{2}{*}{ Causes of deaths } & \multicolumn{2}{|c|}{ Males } & \multicolumn{2}{|c|}{ Females } & \multicolumn{2}{|c|}{ Total } & \multirow[t]{2}{*}{ Pvalue } \\
\hline & No. of deaths & $\begin{array}{c}\text { Rate per } \\
100000 \\
\text { population }\end{array}$ & No. of deaths & $\begin{array}{c}\text { Rate per } \\
100000 \\
\text { population }\end{array}$ & No. of deaths & $\begin{array}{c}\text { Rate per } \\
100000 \\
\text { population }\end{array}$ & \\
\hline $\begin{array}{l}\text { Diseases of blood } \\
\text { and blood forming } \\
\text { organs }\end{array}$ & 438 & 16.1 & 327 & 12.2 & 765 & 14.17 & 0.841 \\
\hline $\begin{array}{l}\text { Congenital } \\
\text { anomalies }\end{array}$ & 205 & 7.5 & 180 & 6.7 & 385 & 7.13 & 0.141 \\
\hline $\begin{array}{l}\text { Diseases of } \\
\text { genitourinary system }\end{array}$ & 215 & 7.9 & 154 & 5.8 & 369 & 6.84 & 0.592 \\
\hline $\begin{array}{l}\text { Disorders of nervous } \\
\text { system }\end{array}$ & 207 & 7.6 & 134 & 5.0 & 341 & 6.32 & 0.151 \\
\hline $\begin{array}{l}\text { Diseases of digestive } \\
\text { system }\end{array}$ & 177 & 6.5 & 131 & 4.9 & 308 & 5.71 & 0.841 \\
\hline $\begin{array}{l}\text { Endocrine and } \\
\text { metabolic diseases }\end{array}$ & 44 & 1.6 & 48 & 1.8 & 92 & 1.70 & 0.077 \\
\hline Others* & 50 & 1.8 & 57 & 2.1 & 107 & 1.98 & 0.033 \\
\hline Total & 6892 & 253.1 & 5219 & 195.2 & 12111 & 224.39 & \\
\hline
\end{tabular}

\section{Discussion}

Erbil, like most other cities in Iraqi Kurdistan, is undergoing a demographic transition involving a decrease in the rate of mortality due to communicable diseases as a result of improvement in the quality of health services provided. However, there an increase in the rate of noncommunicable diseases such as cancer and circulatory diseases, possibly due to changes in lifestyle, unhealthy diets, physical inactivity, smoking and other risk factors (11).

Although crude death rate cannot be used for comparison between countries, due to country-specific age structures (12), it was not possible to calculate the ASDR for the whole study period as data on age structure of Erbil population at KRSO were only available for the years 2009, 2010 and 2011. However, calculation of ASDRs for the available years revealed a similar trend of gradual increase.

Data on ASDRs for neighbouring countries and other states in the Eastern Mediterranean Region (EMR) could not be obtained. The crude death rate of 3.2/1000 population in 2011 is similar to that of Saudi Arabia (3.2), but it is higher than that of Kuwait (1.9), Bahrain (1.9), and Qatar (1.4). However, it is lower than that of Egypt (5.1), Islamic Republic of Iran (5.3), Turkey (4.8), Jordan (4.0), Syrian Arab Republic (3.9) and Oman (3.8). It is also much lower than the EMR rate as well as the global rate in 2011 (6.3 and 7.9, respectively) (13). The crude death rate of $3.2 / 1000$ in 2010 is lower than that of Iraq (excluding Kurdistan Region) in 2010 (4.2/1000) (8), which might be related to improvement in healthcare services and better stability and security in Kurdistan region compared to other parts of Iraq.

The finding of higher male death rates is consistent with male mortality in other parts of Iraq and a number of other neighbouring countries such as the Islamic Republic of Iran (14), Kuwait, Jordan, Turkey, Bahrain and Egypt (15). Male predominance of deaths is also consistent with the WHO report of global burden of diseases for 2008 (16), and the reports of the Australian Bureau of Statistics of 2010 (17). The pattern of age-specific death rates for the last three years of the study is similar to that of Basra (3) and neighbouring countries especially Kuwait, Syrian Arab Republic and Saudi Arabia, where death rates were highest in old and middle-aged demographics (18).

Infant mortality has been regarded as one of the important indicators of health status of any country (19). The IMR in this study in 2008 (20.9/1000 live births) is lower than that reported in Iraq (36), Egypt (30), Islamic Republic of Iran (27), EMR (57) and globally (45). However, it is higher than that reported in Bahrain (9), Qatar (12), Saudi Arabia (20), Syrian Arab Republic (14) and Kuwait (9) (20). The high IMR in this study and Iraq in general, when compared with those of adjacent Gulf countries and the Syrian Arab Republic, could be attributed to the deterioration of health services and socio-economic conditions of the Iraqi population due to economic sanctions in the 1990 s and internal conflicts after the invasion in 2003.

Since the signing of the United Millennium Declaration in 2000, many efforts had been done to reduce $\mathrm{U}_{5} \mathrm{MR}$, but attaining the MDGs is unachievable without reducing infant deaths (21). In Iraq the U5MR was one of the highest in the EMR prior to 1996 after the First Gulf War, and before the implementation of UN's Oil-forFood Programme, when it was estimated to be near 87 deaths/10oo live births (22). Deaths in the neonatal period accounted for about half of under-five mortality (8). The U5MR in Erbil in 2011 is lower than that reported for the whole of Iraq (38 deaths/100o live births) and Islamic Republic of Iran (25), but higher than that reported in 
neighbouring countries such as Kuwait (11), Oman (9), Syrian Arab Republic (15), Saudi Arabia (9) , Jordan (21), Egypt (21), Bahrain (10) and Turkey (15) for the same year (23). According to the Iraq Multiple Indicator Survey (MICS) of 2011, IMR in Kurdistan region was 28/1000 and the U5MR was 32/1000, which are higher than those of Erbil in 2011 (18.8 and 22.5/1000, respectively) (24).

Regarding the trends of mortality rate in the study period, it is evident that cause-specific death rates decreased between 2007 and 2009, except for cancer, which increased after 2008. After 2009, mortality rates for all leading causes of deaths were increasing except for disorders of the respiratory system. The finding that accidents formed the primary cause of death in Erbil $(29.1 \%)$ is inconsistent with that reported in Saudi Arabia in 2005 where accidents was the 5 th leading cause of death (25), and with that reported in Basra Governorate of Iraq in 2007, where diseases of the circulatory system was the primary cause of death (3). In the Islamic Republic of Iran, $14.6 \%$ of deaths were due to accidents (26). Diseases of the circulatory system were the and leading cause of death (25.5\%) in Erbil; a finding which is consistent with that reported in Saudi Arabia (25) and with the WHO report of global burden of diseases of 2008 (16). However, it is inconsistent with the reports of the Australian Bureau of Statistics of 2010 (17), and with the findings of studies in Basra (3), Thailand (27), and the West Bank in Palestine (28), where diseases of the circulatory system were the first leading cause of death.

Our finding that disorders of the respiratory system were the third leading cause of death concurs with that reported in Saudi Arabia (25). However, it is inconsistent with that of Basra, where respiratory disorders were the seventh leading cause of death (3).

Cancers were the fourth leading cause of death, while in Saudi Arabia they were the first leading cause of death (25), and in Basra, they were the second leading cause of death (3). After 2008, cancer death rates showed a gradual increase, possibly attributed to improvement in registration of cancer deaths or a move towards a more Western lifestyle and dietary habits $(11,29)$. In Australia, cancers were responsible for $30.2 \%$ of all deaths registered in 2010 (17), while in the current study they were responsible for only $7.9 \%$ of all deaths.

The finding that accidents were the leading cause of death in the study period could be attributed to the increase in deaths due to RTA in Iraq $(30,31)$ and Kurdistan Region (32) and burns in Kurdistan Region (33-35). Burns are usually suicidal (self-burning) in nature, although some of them might be homicidal and reported as suicides, and mostly reported among females. In the Iraqi injury surveillance project 2010-2011 (30), deaths due to gunshot injuries followed that due to RTA in Iraq in general. The fact that around $28 \%$ of deaths lack data on cause of death, and are usually referred from the courts, could also be responsible for the high proportion of accidents and injuries. Most of the deceased in such cases were old and most probably died from diseases of the circulatory system, disorders of the respiratory system and cancer. However, diseases of the circulatory system were the leading cause of death in 2010 and 2011.

\section{Conclusion}

Mortality in Erbil has a similar pattern of age-specific death rates of that found in neighbouring countries where deaths are concentrated in old and middle-age demographics. Inaccurate identification of the cause of death suggests that the only use of a death certificate in Erbil is for the purpose of burial and legal issues. This highlights the need for urgent educational efforts to achieve complete death registration, including cause of death, which is required for properly identifying healthcare priorities.

\section{Funding: None.}

Competing interests: None declared.

\section{Tendances de la mortalité à Erbil (Iraq), 2007-2011 \\ Résumé}

Contexte : Il est essentiel de disposer d'informations fiables et valables sur les tendances de la mortalité et les causes communes de décès pour orienter les priorités en matière d'allocation des ressources dans le secteur de la santé afin d'améliorer les services de santé pour la population, d'accroître la longévité et d'améliorer la qualité de vie.

Objectifs : La présente étude visait à déterminer les taux de mortalité bruts spécifiques, par sexe, par âge et par cause et à examiner les tendances de la mortalité sur une période de cinq ans entre 2007 et 2011 à Erbil en Iraq.

Méthodes : Cette étude a porté sur 16780 décès enregistrés à l'Unité des statistiques de la Direction de la Santé, de la ville d'Erbil. Les données ont été examinées et validées à des fins d'analyse. Les causes de décès ont été classées en fonction des systèmes corporels.

Résultats : Le taux brut moyen de mortalité était de 3,1 pour 1000 habitants, avec une prédominance des hommes par rapport aux femmes dans toutes les années de l'étude (3,5 et 2,7-2,5) respectivement. Les taux de mortalité par âge étaient élevés dans les groupes des personnes âgées et des personnes d'âge moyen, en plus de ceux des moins de 5 ans. Les accidents et les maladies circulatoires étaient les principales causes de décès avec des taux de 65,2 et 58,3/100 000 habitants respectivement.

Conclusions : Une identification précise de la cause du décès laisse supposer que le certificat de décès à Erbil n'est utilisé qu'à des fins d'inhumation et du fait de problèmes juridiques, et qu'il est donc impératif de déployer des efforts éducatifs pour parvenir à un enregistrement complet et détaillé du décès. 


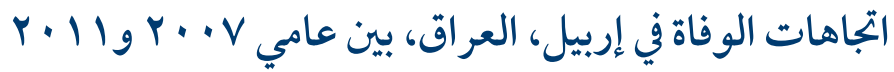 أسو زنكنة، هيثم البنا، طارق الحديثي

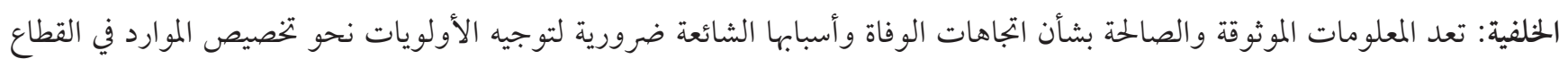
الصحي، بهدف تعزيز الخدمات الصحية للسكان وزيادة طول العمر وتحسين جودة المونة الحياة.

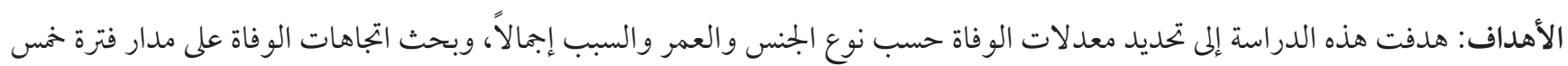

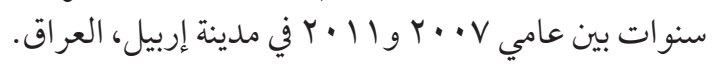

طرق البحث: وصلت هذه الدراسة إلى • 1 IVA وفاة مسجلة في وحدة الإحصاء التابعة لمديرية الصحة، مدينة إربيل. وتم استعر اض البيانات

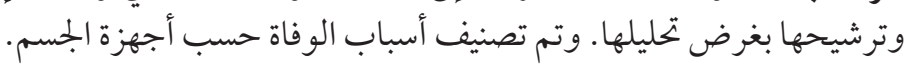

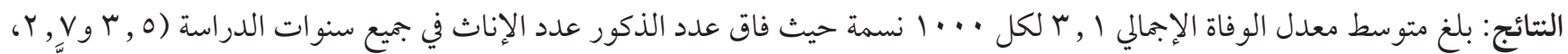

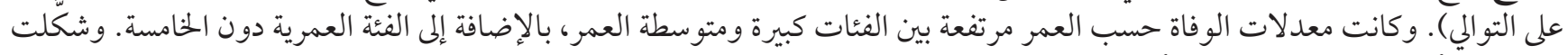

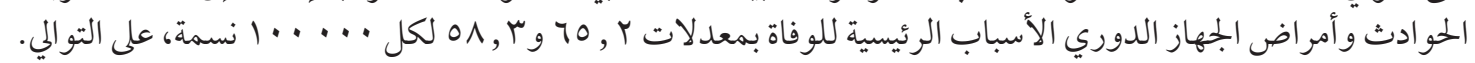

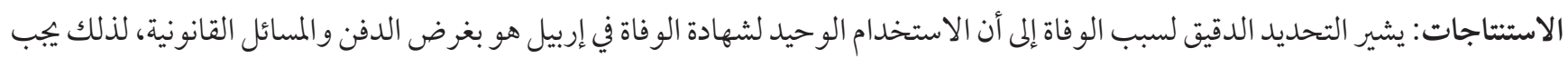

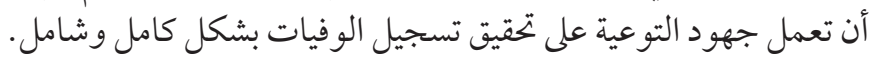

\section{References}

1. United Nations. Changing levels and trends in mortality: the role of patterns of death by cause. New York: Department of Economic and Social Affairs; 2012.

2. Mathers CD, Boerma T, Fat DM. Global and regional causes of death. Br Med bull. 2009 ;92(1):7-32.

3. Sadek H, Ajeel N. Age-standardized mortality rates by cause in Basra, Iraq: 1978 and 2007. East Mediterr Health J. 2012;18(10):1049-54

4. Rao C, Bradshaw D, Mathers CD. Improving death registration and statistics in developing countries: lessons from Sub-Saharan Africa. S A J Dem. 2004;9(2):81-99.

5. Yang G, Hu J, Rao KQ, Ma J, Rao C, Lopez AD. Mortality registration and surveillance in China: History, current situation and challenges. Population Health Metrics. 2005;3(3).doi:10.1186/1478-7954-3-3

6. Awqati NA, Ali MM, Al-Ward NJ, Majeed FA, Salman K, Al-Alak M, et al. Causes and differentials of childhood mortality in Iraq. BMC Pediatrics. 2009;9(1):40.doi:10.1186/1471-2431-9-40

7. World Health Organization. Medical certification of cause of death: instructions for physicians on use of international form of medical certificate of cause of death. 4th ed. Geneva: World Health Organization; 1979 (http://www.who.int/iris/handle/10665/40557).

8. Kurdistan Region Statistical Office (KRSO). Erbil population. Erbil, Iraq: KRSO; 2013.

9. World Health Organization. International classification of diseases. 9th revision (ICD-9). Geneva: World Health Organization; 1975.

10. Ahmad O, Boschi-Pinto C, Lopez AD, Murray CJL, Lozano R, Inoue M. Age standardization of rates: A new WHO standard. Geneva: World Health Organization; 2001.

11. Al-Hadithi T, Shabila N, Al-Tawil N, Othman S. Demographic transition and potential for development: the case of Iraqi Kurdistan. East Mediterr Health J. 2010;16(10):1098-102

12. 1Haupt A, Kane TT, Haub C. PRB's population handbook. 6th ed. Washington, DC: Population Reference Bureau; 2011.

13. World Health Organization. World Health Statistics 2013. Geneva: World Health Organization; 2013.

14. Khosravi A, Taylor R, Naghavi M, Lopez AD. Mortality in the Islamic Republic of Iran, 1964-2004. Bull World Health Organ. 2007; 85(8): 607-14.

15. World Health Organization. World Health Statistics 2012. Geneva: World health Organization; 2012.

16. Mathers C, Fat DM, Boerma J. The global burden of disease. Geneva: World Health Organization; 2008.

17. Australian Bureau of Statistics. Causes of death. Canberra: Australian Bureau of Statistics; 2012.

18. World Health Organization. World Health Statistics Report 2006. Geneva: World Health Organization; 2007.

19. Lopez A. Pacific Health Dialog. Health Information System. Journal of Community Health and Clinical Medicine for the Pacific 2012; 18(1): 247-71.

20. World Health Organization. World Health Statistics 2010.Geneva: World Health Organization; 2010. 
21. Reidpath D, Allotey P. Infant mortality rate as an indicator of population health. J Epidemiol Community Health. 2003;57(5):344-6.

22. Garfield R, Leu CS. A multivariate method for estimating mortality rates among children under 5 years from health and social indicators in Iraq. Int J Epidemiol 2000; 29(3):510-5.

23. You D, Wardlaw T, Boerma T, Mathers C, Inoue M, Oestergaard M, et al. Levels \& trends in child mortality report 2011. New York: UNICEF, WHO, The World Bank, and United Nations Population's Division; 2011.

24. UNICEF, KRSO, CSO, MoH. Iraq Multiple Indicator Survey 2011. Baghdad: MoH \& MoP; 2012.

25. Ansary LA, Esmaeil SA, Adi YA. Causes of death certification of adults: an exploratory cross-sectional study at a university hospital in Riyadh, Saudi Arabia. Ann Saudi Med. 2012; 32(6):615-22.

26. Akbari M, Naghavi M, Soori H. Epidemiology of deaths from injuries in the Islamic Republic of Iran. East Mediterr Health J 2006; 12(3/4): 382-90.

27. Rao C, Porapakkham Y, Pattaraarchachai J, Polprasert W, Swampunyalert N, Lopez AD. Verifying causes of death in Thailand: rationale and methods for empirical investigation. Population Health Metrics. 2010;8(1):11.doi:10.1186/1478-7954-8-n

28. Abu-Rmeileh NM, Husseini A, Abu-Arqoub O, Hamad M, Giacaman R. Mortality Patterns in the West Bank, Palestinian Territories, 1999-2003. Preventing Chronic Disease. 2008;5(4):A112.PMC2578778

29. Othman RT, Abdulljabar R, Saeed A, Sadiq S, Kittani HM, Mohammed SA, et al. Cancer incidence rates in the Kurdistan Region/ Iraq. Asian Pac J Cancer Prev. 2011;12:1261-4.

30. Saleh A. Iraqi injury surveillance project 2010-2011. The fourth annual conference. Human resources training and development center. Ministry of Health, Baghdad, Iraq, 6-8 December, 2012.

31. Jetheer AA, Alaani N, Al-Lami F. Incidence and pattern of road traffic injuries, Missan, Iraq, 2011. The fourth annual conference. Human resources training and development center. Ministry of Health, Baghdad, Iraq, 6-8 December, 2012.

32. Nakshabandi MM. Casualties and deaths from road traffic accidents in Dohuk, Iraq. Duhok Med J. 2007;1:15-22.

33. Shabila NP, Al-Hadithi TS, Al-Tawil NG, Faidulla RM. Epidemiology of burn injury in Erbil Governorate: A hospital-based study. JABHS. 2010;11(1):55-61.

34. Qader AR. Burn mortality in Iraq. Burns. 2012;38(5):772-5.

35. Othman N. Suicide by self-burning in Iraqi Kurdistan: description and risk factors. Arch Suicide Res. 2011;15(3):238-49. 